\title{
Effectiveness of Think-Pair-Square Strategy on Students' Reading Comprehension
}

\author{
Warno Edi \\ English Education Department \\ University of Riau Kepulauan \\ warnopyaar@yahoo.com
}

\begin{abstract}
This research is about the effects of Think-Pair-Square (TPR) strategy on the reading comprehension of Seventh grade students' at SMPN 16 Batam. It is purpose to find out the effect of TPR strategy on the reading comprehension. To achieve the objectives of the research, the researcher conducted experimental research. This experimental research was held at SMPN 16 Batam. The population in this research is all students of eight grade students at SMPN 16 in academic year 2014/2015. The researcher conducted research in one class. The first class is (VII.4) was as experimental class. The experimental class was taught reading descriptive text using TPR strategy. In analyzing the data, the researcher used a quantitative measurement to find the result. The analysis of the data showed that there was a significant difference of the students' achievement before conducted treatment 62.17 for experimental class. The average of the students' achievement after conducted treatment in experimental class was 87.33. The implication of this research seems to be applicable for seventh grade students. This strategy encouraged the students to be more active during the learning process. The suggestion is the students should know about this strategy. It will make easier while learning if they understand about the rule and procedure. To the other research, the researcher expects to understand well about this strategy in order to make easy for doing further research. Based on this finding, it can be concluded that the use of TPR strategy give significant effect in reading comprehension than the use of other conventional method.
\end{abstract}

Keywords: TPR strategy, reading comprehension, experimental research

\section{INTRODUCTION}

The paradigm of education becomes an important focus in order to improvements, as it relates to the interest of all people. School as an educational institution always need innovative improvements in obtain with the demands of public society. The changes of educational paradigm begin from knowledge transfer that emphasizes to the process of teaching based on the abstract and tend to be passive and monotonous so the students get bored in learning. The dynamic education began to shift of learning process based on 
contextual issues becomes an active learning by developing materials optimizing the available resources. A lot of methods are born from changes variety becomes a choice for educators to deliver the teaching process. The kinds of teaching models, likes traditional learning now becoming unused as the constructivist approach. Among the various models of learning are much in demand by educators, one of the learning methods of getting response is cooperative learning models. In cooperative learning students are require to be more active in communication and social interaction to achieve the learning objectives, while the teachers act as the facilitator and mediator for student's activity. According to Lie (2002) in Isjoni (2010:25) cooperative learning is provide the theoretical basis of how students can successfully learn with others." In this study, the researcher focused on the Think-Pair-Square strategy. Think-pair-square strategy was first developed by Spencer Kagan in 1992 in San Juan, New York. This technique can be used by teachers as an indicator and the media in the deliver of learning objectives to be easy accepted by students. Think-Pair-Square strategy can be applied to various objects into a learning tool. As one object is Reading Comprehension. From the explanation, the researcher is interested in taking the title of "The Effectiveness Of Think-pair-Square Strategy on Students Reading Comprehension at seventh grade students at SMP 16 Batam.”

In this process the readers interact dynamically with the text as people tries to elicit the meaning and where various kinds of knowledge are being used: linguistic or systemic knowledge (through bottom-up processing)" (Alyousef, 2006:64). Reading is an inseparable part of any English course. Learning to read refers to reading for meaning or comprehension. Next, Jain and Parel (2008:113) state "Reading is an active process which consist of recognition and comprehension skill”.

From the explanation above, people should be able to decode (sound out) the printed words and also comprehend what people's read. The goal of reading is to comprehend the meaning. The important thing in reading process is reading comprehension. Comprehension depends on the ability to get individual word meanings. Good readers have to learn to interpret word meanings to the context.

Linse (2005:71) state that "Reading comprehension refers to reading for meaning, understanding and entertainment". To understand text in meaningful, readers need to integrate the meanings of success sentence and how the information fits together as a whole, that is global coherence. 
McNamara et.all (2007:107) state that "reading comprehension test is a critical part of designing and implementing programs that teach reading strategies". The purpose of the test is to observe and measure the level of the target readers.

\section{METHODOLOGY}

The study of this research is a quantitative study with pre-experimental design. Gay and Airasian (2012:7) state that "quantitative research is the collection and analysis numerical data to describe, explain, predict, or control of phenomena of interest.

\section{RESULTS}

The students score are distributed into 2 categories: (1) The scores of preexperimental and (2) The scores of post-experimental. The student's scores in each category is as follows:

\section{1) The Scores of Pre-Experimental}

The highest scores of student's reading comprehension before given treatment by using T-P-S (Think-Pair-Square Strategy) in experimental class highest score was 80, while the lowest score was 40 , the mean score was 62.17 and the standard deviation was 8.97.

Table 1. Score of pre-test of experimental class

\begin{tabular}{cccccc}
\hline Class & $\mathbf{N}$ & $\begin{array}{c}\text { The } \\
\text { highest } \\
\text { Score }\end{array}$ & $\begin{array}{c}\text { The } \\
\text { lowest } \\
\text { Score }\end{array}$ & Mean (X) & $\begin{array}{c}\text { Standard } \\
\text { Deviation } \\
\text { (SD) }\end{array}$ \\
\hline Experimental & 30 & 80 & 40 & 62.17 & 8.97 \\
\hline
\end{tabular}

\section{2) The Score of Post-Experimental}

The highest scores of student's reading comprehension after given treatment by T-P-S (Think-Pair-Square Strategy) in experimental class was 100, while the lowest score was 70 , the mean score was 83.33 and SD was 6.99. 
Table 2. Score of post-test of experimental class

\begin{tabular}{cccccc}
\hline Class & $\mathbf{N}$ & $\begin{array}{c}\text { The } \\
\text { highest } \\
\text { Score }\end{array}$ & $\begin{array}{c}\text { The } \\
\text { lowest } \\
\text { Score }\end{array}$ & Mean (X) & $\begin{array}{c}\text { Standard } \\
\text { Deviation } \\
\text { (SD) }\end{array}$ \\
\hline Experimental & 30 & 100 & 70 & 83.33 & 6.99 \\
\hline
\end{tabular}

\section{3) Validity and Reliability}

Before conducting the research, validity and reliability of instrument of reading comprehension was conducted. The instrument uses descriptive text, therefore a validity test by using pearson product moment, and a reliability test by using Kuder Richardson 20 was conducted. Then, a reliability test by using KR 20 was conducted (see table 9), the result could be seen: Rkk: 0,696. Because rkk is higher than $r_{\text {table }}(0.696>0.361)$ at level of significance 0.05 , then it is conclude that the instrument is reliable.

\section{4) Normality and Homogenity}

Before analyze the data by using $\mathrm{T}_{\text {test }}$, normality test must be done. The normality test is used to know whether the sample is in normal distribution or not ( see table 5). It can be seen as follows:

\section{Chi Square}

$$
X^{2}=\sum_{i-1}^{k} \frac{\left(f_{o}-f_{h}\right)^{2}}{f_{h}}
$$

The sample is on normal distribution if $\mathrm{X}_{\mathrm{observed}}<\mathrm{X}_{\text {table }}$ at the level of significance $\alpha=$ 0.05 .

Table 3. Summary of normality testing

\begin{tabular}{lccc}
\hline \multicolumn{1}{c}{ Variable } & $\mathbf{X}_{\text {observed }}$ & $\mathbf{X}_{\text {table }}$ & Note \\
\hline $\begin{array}{l}\text { Pre Test Reading } \\
\text { comprehension of }\end{array}$ & 4.8 & 11.070 & $\begin{array}{l}\text { Xo }<\mathrm{Xt} \\
\text { Experimental Class }\end{array}$ \\
$\begin{array}{l}\text { Post Test Reading } \\
\begin{array}{l}\text { Comprehension of } \\
\text { Experimental Class }\end{array}\end{array}$ & 6.1 & 11.070 & $\begin{array}{l}\text { Xo }<\mathrm{Xt} \\
\text { Normal }\end{array}$ \\
\hline
\end{tabular}




\section{a) Variable ( pre-test)}

Variable pre-test is the data for student's reading comprehension test which consist of 20 multiple choise and 30 students $(n=30)$. The highest value of $X_{0}$ is 4.8 and $X_{\text {table }}$ at the significance level $\alpha=0.05$ is 11.070 . Because $\mathrm{X}_{O}$ is lower than $\mathrm{X}_{\mathrm{t}}(4.8<11.070)$, it can be conclude that the sample is in normal distribution.

\section{b) Variable (Post-test)}

Variable post-test is the data for student's reading comprehension test which consist of 20 multiple choise and 30 students $(n=30)$. The highest value of $X_{o}$ is 6.1 and $X_{\text {table }}$ at the significance level $\alpha=0.05$ is 11.070 . Because $X_{O}$ is lower than $\mathrm{X}_{\mathrm{t}}(6.1<11.070)$, it can be conclude that the sample is in normal distribution.

The homogeneity test is used to know whether each had the same variance or not. It can be seen as follows:

\section{F Test}

$$
F_{\text {observed }}=\frac{\text { largest variance }}{\text { smallest variance }}
$$

The variance were homogenous if $\mathrm{F}_{\text {observed }}<\mathrm{F}_{\text {table }}$ at the level of significance $\alpha=0.05$

Table 4. The summary of homogenity testing

\begin{tabular}{llccc}
\hline No & Variable & Fobserved $_{\text {table }}$ & Conclusion \\
\hline 1. & Pre test & 1.64 & 1.85 & Homogenous \\
\hline 2. & Post Test & 1.64 & 1.85 & Homogenous \\
\hline
\end{tabular}

Fobserved for students' pre test and post test reading comprehension (1.64) was lower than the ratio of $\mathrm{F}_{\text {table }}$ with the degree of freedom 29 and significant level $5 \%$ is 1.85. It means that $\mathbf{F}_{\text {observed }}<\mathbf{F}_{\text {table, }}$ or $1.64<\mathbf{1 . 8 5}$. So it can be conclude both of the variances were homogenous. 


\section{DISCUSSION}

Based on the calculation of pre- test and post-test in experimental class. The mean score of experimental group for pre-test was 62.17, while the mean score for post-test was 83.33. It was shown that the students who got treatments with Think-Pair-Square (TPS) Strategy were higher score. Based on the regression for hypothesis with $\alpha=5 \%$ of significance level and the value of t-table of the level of freedom 29. The value t-obtained (60.49) was bigger than the value of t-table (1.699), the alternative hypothesis was accepted and the null hypothesis was rejected. It can be concluded that Think-Pair-Square strategy give the significance effect on reading comprehension. it can be concluded that the students who were taught by using Think-Pair-Square (TPS) Strategy give the significance effect on reading comprehension.

The success of this research can be proved by the students' score in the pre-test and post-test. To make students interest to the learning activity, the teacher should use suitable learning strategies in the class. The teacher must choose one of learning strategies which suitable to the material and conditions of the students. To learn English, especially for reading by using Think-Pair-Square the students should know about the strategies. It will make easier while learning process if they understand about the rule and the purpose of learning.

By Think-Pair-Square strategy the learning process more effective and communicative, so it will make English learning be better. Since this research had been finished and got the data conclusion about the comparison of reading using pair discussion of cooperative learning and other conventional method. The researcher expects for other researcher to understand well about this research in order to make easy for doing further research.

\section{REFERENCES}

Alyousef, H. (2006). Teaching reading comprehension to ESL/EFL Learners: Journal of Language and Learning. Vol 5 (1).

Gay,L.R and Airasian. (2012). Educational research: Competencies analysis and applications. America: Library of Congress Cataloging-in-Publication Data. 
Isjoni, H. (2010). Pembelajaran kooperatif: Meningkatkan kecerdasan komunikasi antar peserta didik. Sejarah pembelajaran kooperatif. Yogyakarta: Pustaka Belajar.

Jain and Patel. (2008). English language teaching (Methods, tools \& techniques). Jaipur: Sunrise Publisher \& Distribution..

Linse, T. (2005). Practical English language teaching: America: Young Learners.

MCnamara, S. (2007). Reading comprehension strategies: Theories, interventions and technologies. New York: Lawrence Erlbaum Associates Library of Congress Catalogingin-Publication Data. 